ISSN 0258-7122 (Print), 2408-8293 (Online)

Bangladesh J. Agril. Res. 44(3): 401-408, September 2019

\title{
SOCIO ECONOMIC ASPECT OF ORGANIC FARMING PRACTICES FOR IMPROVING FARMER'S INCOME IN SOME LOCATIONS OF KERALA, INDIA
}

\author{
N. KARUNAKARAN ${ }^{1}$ AND M. S. SADIQ ${ }^{2}$
}

\begin{abstract}
Agriculture is the major source of livelihood and is under the big threat of liberalization and modernization. Organic farming is eco-friendly, promotes sustainable development, protects the fertility of the soil and ensures long term crop income to the farmer. In 2018, total area under organic certification process is 3.56 million hectare and produced around $\mathbf{1 . 7 0}$ million MT of certified organic products. In Kerala, the total area under organic farming stands at 15790.49 hectare. Organic farmers fail to capture the market for selling their products and have less capacity in the competing world, leads to worse financial situation of farmers. The total volume of export during 2017-18 was 4.58 lakh MT. Fair trade has flourished as an initiative for lifting poor organic farmers by providing higher price, credit and improved community life. It is also a market for high value products in the global trade policies. Fair Trade Alliance Kerala (FTAK) is a small farmers' organisation to access global market on fair trade in an equitable trading terms and improved income. The system provides better price to products compared to open market and benefited fair trade exporting. This paper by studying FTAK focused the impacts of it on income and highlights the increased production of organic crops, better prices, premium and schemes to farmers. The study revealed that fair trade farmers earned higher price (20 to 50 percent) for commodities and marketing of products to foreign countries without intermediaries and organic farming is a better option for increasing farmer's income in India.
\end{abstract}

Keywords: farmers' income; Fair Trade Alliance Kerala; organic Farming: India

JEL Classification: Q7; Q10; Q11; Q16.

\section{Introduction}

Organic farming in India over the years is growing and is important in the present day economy. The area under different organic practices across the country is very high and different agencies involved directly and indirectly in promoting organic farming. It includes: government agencies, non-governmental organizations and farmer's groups. In addition, there are many farmers isolated from formal groups and agencies. Major government agencies involved in the promotion of organic farming are the Department of Agriculture, Panchayath Raj

${ }^{1}$ Head of the Post-graduate Department of Economics, EKNM Government College Elerithattu, 671314, Kasaragod, Kerala, India, ${ }^{2}$ Department of Agricultural Economics and Extension Technology, FUT, Minna, Nigeria. 
Institutes, Agricultural Universities, State Horticultural Missions, State level offices of the Commodity Boards (like Spices Board, Tea Board and Coffee Board), and NABARD. Non-governmental organizations were active for promoting poison-free agriculture and used different concepts, approaches and methods (Karunakaran and Silna Thomas, 2017). There is an increasing tendency among farmers for ruthless conversion of land for cash crops, indiscriminate use of insecticides and chemical fertilisers. In the light of existing problems, farmers have to provide access to the required inputs and knowhow for alternate organic methods of farming.

Fair Trade is an organised social movement aims to help producers in developing countries for better trading condition and sustainable agriculture. This implies certification that advocates higher price and better social and environmental standards (Benjamin, 2000). It focused particularly on exports from developing countries to developed countries most notably, handicrafts, coffee, cocoa, sugar, cashewnut, tea, bananas, honey, cotton, wine, fresh fruits and gold. There are a number of fair trade and ethical marketing organisations with different marketing strategies over the last twenty years (Kristen, 2011). Most fair trade organisations are members certified by several national and international federations. Fair Trade Labelling Organisation International (FLO) is named as Fair Trade International in 2009 (Reynolds, 2012). In India, fair trade movement opened huge markets for farmers.

Fair Trade Alliance Kerala (FTAK) was formed in 2005 in the Malabar Coast of India. It draws its membership and charter from mass movement of farm houses, struggled against rural appropriation and indebtedness (John, 2012). Among the farmers, 50 percent are certified organic and the aim is 100 percent. FTAK farmers grow a host of crops like cashew-nut, coconut, coffee, cocoa, pepper, vanilla and other spices. In mid-2000s, particularly in south-western India, FTAK addressed the devastating impact of fluctuating market prices on the ability of small farmers to earn a stable income. The prices in the global market fluctuated dramatically and the farmer's ability to plan and make investment affected. FTAK members are participating in fair trade system, exports, assure minimum price above market price and plan more confidently their future and reinvest in their farms for social projects (Karunakaran and Libin, 2014). Fair trade thus is a social movement with stated goal to help farmers to achieve better trade, income and promote sustainability (Kristen, 2011) in organic farming. In this context, this paper made an attempt to examine organic farming as an option for increasing farmer's income in India by analysing Fair Trade Alliance Kerala as a case in terms of price of products, socio-economic condition of farmers, living standard, sustainability of organic farming and schemes adopted by fair trade. More specifically, the main objectives of the study include:

(i) To examine organic farming as an option for increasing farmer's income in India, and 
(ii) To analyse Fair Trade Alliance Kerala as a case by examine the price of products, socio-economic conditions, living standards, sustainability of farming and schemes in fair trade.

\section{Materials and Methods}

FTAK in Kerala was taken as a case and is mainly concentrated in the districts of Kasaragod, Kannur, Kozhikode and Wayanad. Among these districts, primary data were collected from 120 farmers from three panchayaths of Kasaragod, Kannur and Wayanad districts, taking one panchayath from each district. Data were collected from these 120 farmers taking 40 farmers from each panchayath for pepper, ginger, turmeric, cocoa, coconut and cashew-nut crops during the period of 2018. Primary data is obtained directly from the farmers of these panchayaths through questionnaire, interview schedule and focus group discussions. Secondary data were collected from published reports, personal and FTAK records and fair trade alliance branches in Kerala. Statistical tools like simple growth rate, percentages and diagrams were used for analysis.

\section{Results and discussion}

3.1. Fair Trade Alliance Kerala (FTAK), origin and growth: Fair trade means a trading partnership based on dialogue, transparency and respect that seeks greater equity in the international trade (Karunakaran and Silna Thomas, 2017). Fair Trade Alliances Kerala was founded in 2005 by Kerala's first organic store elements in Kozhikode, which was seeking to offer local market access to the growing number of organic farmers in Kerala. It is a mass based, farmers led movement in Kerala focusing solely on justice and concern in trade, positioned to offer fair trade market for high value products (Karunakaran and Libin Thomas, 2014).

Initially, Fair Trade Alliance Kerala was formed with 4500 farmers of Kannur, Kasaragod, Wayanad and Kozhikode (Karunakaran and Silna Thomas, 2017). It is uniquely positioned to offer fair trade market to products including cocoa, coffee, cinnamon, turmeric, cashewnut, ginger, pepper, cardamom and coconut. FTAK also aimed to enable farmers the access to global market and improved income through fair trade. The basic idea behind this is to promote sustainable development through trade and works according to a range of fair trade principles like fair price, fair labour condition, direct trade, commodity development and environmental sustainability (Chamorro, 2005). Organic marketing and fair trade are quite different from that of regular marketing and free trade (Benjamin, 2000). In Kerala among Kasaragod, Kannur, Wayanad and Kozhikode districts, around 34500 farmers have memberships in FTAK. Kannur district have the highest farmers membership (1870) and highest total area (3008 hectare) compared to other districts. Among 5804 hectare land existed, 1572 hectare is organic and 2255 hectare land is in-conversion (Table 1). 
Table 1: Organic farmers and area cultivated in Fair Trade Alliance Kerala

\begin{tabular}{c|c|c|c|c|c}
\hline Sl. No. & Districts & $\begin{array}{c}\text { Number of } \\
\text { Farmers }\end{array}$ & $\begin{array}{c}\text { Total Area } \\
\text { (in Hectare) }\end{array}$ & $\begin{array}{c}\text { Organic Area } \\
\text { (in Hectare) }\end{array}$ & $\begin{array}{c}\text { In-conversion } \\
\text { Area (in Hectare) }\end{array}$ \\
\hline 1 & Kasaragod & 923 & 1879 & 510 & 620 \\
2 & Kannur & 1870 & 3008 & 644 & 1202 \\
3 & Wayanad & 513 & 616 & 298 & 259 \\
4 & Kozhikode & 144 & 301 & 120 & 174 \\
& Total & 34500 & 5804 & 1572 & 2255 \\
\hline
\end{tabular}

Source: Karunakaran and Libin Thomas (2014)

FTAK aims to ensure small scale farming a sustainable occupation. The main objectives of FTAK include: (i) to promote the overall welfare of farmers by enhancing unity among farmers, introducing agricultural operations for nature and human community and ensure participation of farmers in production, processing and distribution of agricultural products; (ii) to introduce plans and programmes for farmers to market their products at a reasonable price; (iii) to promote ancillary activities for making agriculture profitable; (iv) to promote the quality of agricultural products; (v) to encourage self confidence, mutual understanding and unity among farmers; and (vi) to constitute cells of farmers at panchayath, district and state levels.

FTAK followed organic and poison-free farming, and productivity increased (Table 2); compared to 2009 it increased to 180 percent in 2017, showing continuous increase in productivity.

Table 2. Productivity growth under organic farming in FTAK

\begin{tabular}{c|c|c}
\hline S1. No & Year & Productivity growth (in \%) \\
\hline 1 & 2009 & 100 \\
2 & 2010 & 106 \\
3 & 2011 & 127 \\
4 & 2012 & 152 \\
5 & 2013 & 161 \\
6 & 2014 & 162 \\
7 & 2015 & 165 \\
8 & 2016 & 171 \\
9 & 2017 & 180 \\
\hline
\end{tabular}

Source: Calculated using primary data taking 2009 as base year

FTAK is democratic in nature and the entire activity is carried out by elected members from the grass root to state level. It provides a platform to sit together and decide the course of action. Since its inception, FTAK has been active in the 
international fair trade commodity market. The flagship products of the organization are cashew, coffee and spices. About 2100 metric tonne of fair trade cashew has been sourced from Kannur and Kasaragod districts under fair trade valued around Rs 200 million (Govt. of Kerala, 2016). FTAK farmers have shifted to organic farming; now all are either organic or working towards it.

3.2. FTAK and price of organic products: Figure 1 show that 47 percent and more depend on fair trade for selling their organic products. From table 3 it is revealed that fair trade alliance offered higher prices to the organic products, and the difference is the highest for pepper, turmeric, cocoa and ginger.

Table 3. Price variation in FTAK and open market for organic products

\begin{tabular}{c|c|c|c|c}
\hline \multirow{2}{*}{ S1. No } & \multirow{2}{*}{ Products } & FTAK & Other markets & Difference (in \%) \\
\cline { 3 - 5 } 1 & Pepper & 400 & 300 & 25 \\
2 & Cashewnut & 140 & 110 & 21 \\
3 & Turmeric & 30 & 15 & 50 \\
4 & Coconut & 45 & 35 & 22 \\
5 & Ginger & 42 & 32 & 24 \\
6 & Cocoa & 155 & 105 & 33 \\
\hline
\end{tabular}

Source: Field survey, 2018

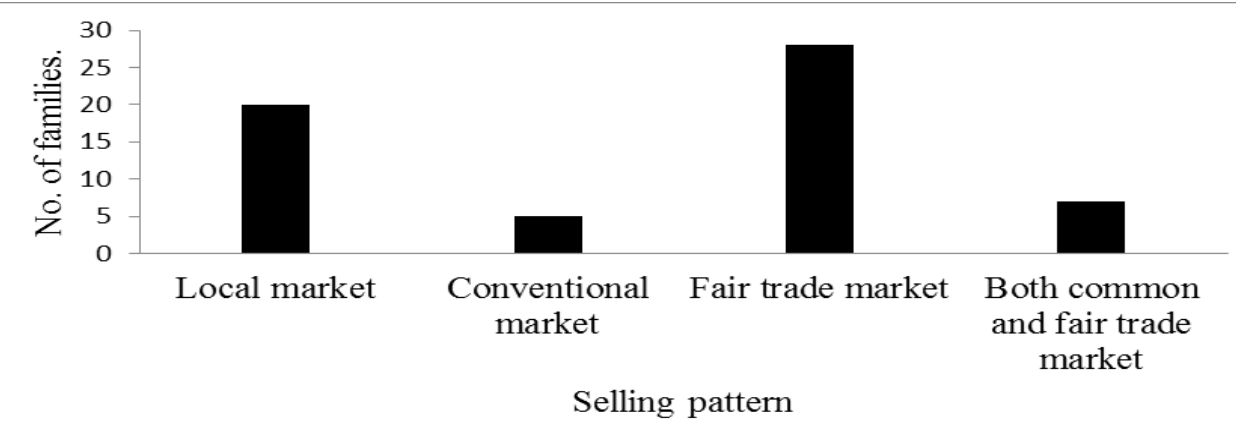

Figure 1: Selling pattern of organic commodities

Table 4: Income from organic farming

\begin{tabular}{c|c|c|c|c}
\hline \multirow{2}{*}{ Sl. No } & \multicolumn{2}{c|}{ Land of households } & \multicolumn{2}{c}{ Annual income of households } \\
\cline { 2 - 5 } & Size of Land (in hectare) & $\%$ & Income (in Rs) & $\%$ \\
\hline 1 & Below 0.2 & 32 & Below 25000 & 17 \\
2 & $0.2-0.4$ & 10 & $25000-50000$ & 25 \\
3 & $0.4-1.6$ & 42 & $50000-1$ lakh & 50 \\
4 & Above 1.6 & 16 & 1 lakh - 4 lakh & 8 \\
\hline \multicolumn{2}{r}{ Source: Field survey, 2018 }
\end{tabular}

Source: Field survey, 2018 
3.3. FTAK and organic farming: Table 4 shows the income generated by selling products and majority earned more than 50 thousand rupees per year. Ninety five percent of coconut farmers, 92 percent of cocoa cultivators, and majority of others are following organic farming practices to earn income (Table $5)$.

Table 5: Main organic crops under cultivation

\begin{tabular}{c|c|c}
\hline S1. No & Crops & Families cultivated (in \%) \\
\hline 1 & Ginger & 72 \\
2 & Pepper & 55 \\
3 & Coconut & 95 \\
4 & Cashewnut & 20 \\
5 & Turmeric & 42 \\
6 & Cocoa & 92 \\
\hline
\end{tabular}

Source: Field survey, 2018

3.4. FTAK and socio-economic conditions of organic farmers: FTAK provided supportive measures for bringing women to the forefront. The aged persons are promoting organic farming compared to others; 75 percent of the farmers belong to the age group of 55 to 75 years in the study area (Table 6).

Table 6: Organic farmers age under FTAK

\begin{tabular}{c|c|c}
\hline Sl. No & Age of farmers & Percent of farmers \\
\hline 1 & $35-45$ & 10 \\
2 & $45-55$ & 12 \\
3 & $55-65$ & 42 \\
4 & $65-75$ & 33 \\
5 & $75-80$ & 3 \\
& Total & 100 \\
\hline
\end{tabular}

Source: Field survey, 2018

3.5. FTAK and various schemes to organic farmers: FTAK also provided different schemes for increasing farming which include: (i) organic agriculture promotion; (ii) distribution of tools; (iii) training; (iv) community kitchen for school children; (v) solar fencing for farmers; (vi) cash awards to farmers; (vii) community water supply; and (viii) women empowerment programme. Table 7 shows the beneficiaries under various schemes and shows that more than 75 percent were benefited from different schemes like animal husbandry, subsidy and medical facilities, 
Table 7: Organic farmer's implemented programmes by FTAK and its benefits

\begin{tabular}{ccc}
\hline Sl. No & Schemes & Benefited Farmers (in \%) \\
\hline 1 & Subsidy & 25 \\
2 & Pension & 8 \\
3 & Grants & 13 \\
4 & Animal Husbandry & 34 \\
5 & Medical Facility & 20 \\
\hline
\end{tabular}

Source: Field survey, 2018

3.6. FTAK and sustainability of the organic sector: FTAK is based on dialogue transparency and respect which provides greater equity in international trade, contributed to sustainable development. Better price, decent working conditions, local sustainability, and fair terms of trade in fair trade enables to improve their position. It also awarded to products to meet the standards and certified.

To FTAK, organic agriculture is the only sustainable agricultural development process to get safe, non toxic food and protect the environment in the farming process. Organic foods are those that are produced using environmentally sound methods that do not involve modern synthetic inputs such as pesticides and chemical fertilizers, do not contain genetically modified organisms, and are not processed using irradiation, industrial solvents and chemical food additives.

Organic farmers earned income from the products based on the quality and quantity of products. The prices of crops are different and income earning capacity also related to the product type. Table 8 shows that 8 percent of the farmers earned below 10000 rupees and 63 percent between 15000-25000 rupees; 12 percent attain more than 25000 rupees from their crops.

Table 8: Organic farmer's income earning capacity under FTAK

\begin{tabular}{c|c|c|c}
\hline Sl. No & Income & Number of farmers & $\%$ \\
\hline 1 & Below 10000 & 10 & 8 \\
2 & $10000-15000$ & 20 & 17 \\
3 & $15001-20000$ & 40 & 33 \\
4 & $20001-25000$ & 36 & 30 \\
5 & Above 25000 & 14 & 12 \\
& Total & 120 & 100 \\
\hline
\end{tabular}

Source: Field survey, 2018

\section{Conclusion and recommendations}

Organic farming is eco-friendly, promotes sustainable development in the environment and protects fertility of soil. Fair Trade Alliance Kerala helps 
organic farming to maintain food security, food safety, fair prices and better socio-economic conditions to farmers. It is a small farmers' organisation created to access the global market on fair trade and equitable trading to improve farmer's income through fair trade minimum price and premium.

From the results of the study it is concluded that fair trade alliance in Kerala has provided for the social and economic developments of farmers. The quality of crops is very high in the study area because the farmers were not using any type of chemical pesticides and fertilizers for the crop. Fair trade not only aimed at the financial uplift of farmers but also the social developments like, women empowerment, environment protection, and sustainable development.

Organic products gained significant social and economic importance as a major foreign exchange earner. It also provided different schemes to organic farmers for increasing their production. From the analysis it is revealed that the programmes of FTAK encouraged agricultural production and productivity. The organic products like pepper, cashewnut, coconut, ginger, turmeric and cocoa have reached high quality from the cultivation and the farmers are benefited in social development, women empowerment and environmental protection. FTAK provided awareness classes to organic farmers and encouraged them by ensuring high prices to the crops. FTAK also helped the farmers for marketing their products in international market and attain better price and increased income. Hence the initiative of the government to increase farmer's income through organic farming practice is essential and authority should develop innovative programmes initiated by FTAK for the promotion of agricultural sector and thereby increase farmer's income for reducing poverty.

\section{References}

Benjamin Huybrechts (2000), "Fair Trade Organization in Belgium: unity in Diversity", Journal of Business Ethics, 92 (2): 21-24.

Chamorro (2005), "Does Fair Trade Make a Difference: The Case of Small Coffee Producers in Nicaragua", Development in Practice, 15 (1): 584-599.

Govt. of Kerala (2016), Economic Review, State Planning Board, Thiruvananthapuram, Kerala: $19-49$.

John Arackal, A. L. (2012), "FTAK, justice in trade conference", Jayva Keralam (Ed), 4 (2): 3-5.

Karunakaran, N. and Libin Thomas (2014), "Fair trade alliance of cashewnut cultivation in Kerala", Southern Economist, 52 (20): 29-32.

Karunakaran, N. and Silna Thomas (2017), "Fair Trade Alliance Kerala and marketing of organic commodities: a case study of Kasaragod", Journal of Management and Technology, 13 (2): 2-6

Kristen Shorette (2011), "Fair Trade and Double Movement: The promise and contradictions of improving Labour standards in the Global South via market Mechanisms", Journal of Workplace Rights, 15 (3-4): 461-481.

Reynolds, L. (2012), "Fair Trade: Social Regulation in Global Food Markets", Journal of Rural studies, 28 (3): 276-287. 